\title{
Carriage of mutations R462Q (rs 486907) and D541E (rs 627928) of the RNASEL gene and risk factors in patients with prostate cancer in Burkina Faso.
}

\section{Essonan Kadanga}

University of Ouagadougou

Abdou Azaque ZOURE ( $\sim$ zabdouazaque@yahoo.fr)

Institute of Health Sciences Research

Théodora M. Zohoncon

Saint Thomas Aquinas University

Lassina Traoré

University of Ouagadougou

Bienvenu Désiré Ky

University of Ouagadougou

Albert Théophane Yonli

University of Ouagadougou

Bapio Bazié

Institute for Research in Applied Sciences

Hermann Karim Sombié

University of Ouagadougou

Pegdwendé Abel Sorgho

University of Ouagadougou

\section{Tovo Frida}

University of Ouagadougou

Clarisse Ouédraogo

University of Ouagadougou

Florencia W. Djigma

University of Ouagadougou

Jacques Simpore

University of Ouagadougou

Aida Traoré

University of Ouagadougou

Kalifou Traoré

University of Ouagadougou 


\section{Research Article}

Keywords: RNASEL, R462Q, D541E, Prostate Cancer, Burkina Faso

Posted Date: November 19th, 2021

DOI: https://doi.org/10.21203/rs.3.rs-1037656/v1

License: (c) (1) This work is licensed under a Creative Commons Attribution 4.0 International License. Read Full License 


\section{Abstract \\ Background}

Prostate cancer (Pca) is a public health problem that affects men, usually of middle age or older. It is the second most common cancer diagnosed in men and the fifth leading cause of death. The RNASEL gene located in 1q25 and identified as a susceptibility gene to hereditary prostate cancer, has never been studied in relation to prostate cancer in Burkina Faso. The aim of this study was to analyze the carriage of RNASEL R462Q and D541E mutations and risks factors in patients with prostate cancer in the Burkina Faso.

\section{Methods}

This case-control study included of 38 histologically diagnosed prostate cancer cases and 53 controls (cases without prostate abnormalities). Real-time PCR genotyping of R462Q and D541E variants using the TaqMan ${ }^{\circledR}$ allelic discrimination technique was used. Correlations between different genotypes and combined genotypes were investigated.

\section{Results}

The R462Q variant was present in $5.3 \%$ of cases and $7.5 \%$ of controls. The D541E variant was present in $50.0 \%$ of cases and $35 \%$ of controls. There is no association between R462Q variants (OR $=0.60 ; 95 \% \mathrm{IC}$, $0.10-3.51 ; p=0.686)$ and $D 541 E$ variants $(O R=2.46 ; 95 \% I C, 0.78-7.80 ; p=0.121)$ and genotypes combined with prostate cancer. However, there is a statistically significant difference in the distribution of cases according to the PSA rate at diagnosis ( $p \otimes 0.001)$. For the Gleason score distribution, only $13.2 \%$ of cases have a Gleason score greater than 7. There is a statistically significant difference in the Gleason score distribution of cases $(p \otimes 0.001)$

\section{Conclusions}

These variants, considered in isolation or in combination, are not associated with the risk of prostate cancer.

\section{Background}

Prostate cancer (Pca) is the second most frequently diagnosed malignant tumour in humans in the world. It is the fifth leading cause of cancer death in humans, with an estimated 1.4 million new cases and 375,304 deaths in 2020 in the world. In Burkina Faso, in the same year, the number of new cases of prostate cancer was 997 out of 4,305 new cases of cancer, with 608 deaths caused. It is the first cancer in terms of incidence in men (and the fifth cancer in both sexes), followed by liver cancer [1]. The etiology of 
prostate cancer has been the subject of numerous studies but remains largely unknown. The risk factors that remain well established are advanced age, ethnicity, family history [2-4]. Indeed, the incidence of prostate cancer is estimated to be 1 in 350 for men under 50 years [5]; 1 in 52 for 50- to 59-year-olds; then $60 \%$ in men over 65 years. Almost $30 \%$ of men over 50 years who died from causes other than prostate cancer have been shown to have histological evidence of prostate cancer at the time of the autopsy [6]. Populations of African descent, such as African Americans, Caribbean, and blacks in Europe had the highest incidences, early disease and more aggressive form compared to other racial and ethnic groups [7]. Men of African descent are estimated to have a relative risk of 9.7 versus 3.9 in Caucasians and 1.6 in Asians when two or more first-degree relatives have prostate cancer [8]. Regarding family history, more than $20 \%$ of patients with prostate cancer report a family history. This can be explained on the one hand by the common sharing of genes; but also on the other hand by a similar pattern [9] of exposure to certain environmental carcinogens and to common lifestyles [10]. The relative risk of prostate cancer for men with a first-degree relative with prostate cancer is estimated to be about 2.5. This risk increases to 5.3 when three or more first-degree relatives are affected. Serum prostate antigen assay and rectal touch are currently the primary screening methods for prostate cancer [11]. However, with the ultimate goal of developing new, more accurate and beneficial biomarkers in the detection, prevention and treatment of this disease, several studies have been conducted to elucidate the molecular mechanisms involved in the genesis and progression of prostate cancer [12]. The high incidence of prostate cancer in African men suggests a genetic predisposition. Initial quantitative genetic analyses of homo and dizygous twins estimated that germ mutations contributed to prostate cancer risk at approximately 40-58\% [13-15]. Linkage analysis and positional cloning were used to successfully map inherited chromosomal regions containing prostate cancer susceptibility genes. The HPC1 (Hereditary Prostate Cancer 1) locus, located on chromosome region 1q24-25, was the first of these loci to be identified in $1996[16,17]$. Since then, several other loci of predisposition to hereditary forms of prostate cancer have been identified: HPCX (Xq27-28), HPC20 (20q13), HPC2 (17p11), PG1 (prostate cancer susceptibility gene 1) (8p22-23), CAPB (1p36) [18]. Three genes for hereditary prostate cancer susceptibility have been identified in three of these loci. This is the RNASEL(2'-5' oligoadenylate synthetase-dependent ribonuclease) gene (HPC1); of ELAC2 (ElaC Ribonuclease Z 2) (HPC2) which encodes a metallo-dependent hydrolase potentially involved in the repair of the inter-strand cross-linking of DNA and the editing of mRNA and finally the MSR1(Macrophage Scavenger Receptor1) (PG1) gene which encodes subunits a macrophage scavenger receptor which is capable of binding to a variety of ligands. [19-23]. Mutations in these different genes have low or moderate penetrance. They influence the way the prostate works and are responsible for about $30 \%$ of prostate cancer [24]. Other high penetration mutations have been identified in the genes regulating: the critical stages of the development process, namely the G84E mutation of the HOXB13 gene [25, 26]; the Q356R, 185delAG, 5382insC and 6174delT mutations in the BRCA2 gene [27]. Studies of these different regions related to prostate cancer in different populations have provided inconsistent results. These observations show the genetic complexity and heterogeneity (environmental and genetic factors) of prostate cancer predisposition. The RNASEL gene, located at 1q24-25, with a size of about 15 kilos pair of bases, and comprising 8 exons; code for ribonuclease 2'-5'-oligoadenaylate (2-5A) -dependent. RNASEL regulates cell proliferation and apoptosis through the interferon-induced 2'-5'A pathway through its 
antiviral and antiproliferative activity [28]. There are many nucleotide variants identified in the RNASEL gene. Seven of them cause changes in the protein sequence. Six variants cause false sense alterations and a rare variant creates a nonsense mutation [29]. The most commonly studied synonymous variants in association with prostate cancer in different types of populations are R462Q and D541E. R462Q reduces the ability of the cell to cause apoptosis in response to 2'-5'A activation and also has three times less enzymatic activity than normal, while D541E does not affect the function of the Rnase $L$ protein $[18$, 19]. The results of these studies remain contradictory. The AA genotype in R462Q has been associated with both an increased risk of prostate cancer in the United States and in some Caucasian population groups [30,31] and a decreased risk in Caucasian and Japanese sample groups. Previous studies on the RNASEL variant D541E indicated that the GG and TT genotypes were associated with an increased risk of prostate cancer in some Japanese [32] and European-American [33] populations, respectively. On the other hand, a negative association of the TT genotype with prostate cancer in Swedish Caucasian samples was reported by Wiklund et al. in 2004 [34]. In summary, several studies provide strong support, both functional and epidemiological, that RNASEL plays a role in prostate cancer, but other studies have suggested a lack of role based on the ethno-geographic origins of study populations. In West Africa, several studies of prostate cancer in different populations have focused on the epidemic and morphological aspects of prostate cancer [35-37]. Very few studies have examined the genetic background of African populations and its contribution to prostate cancer susceptibility. This limits the use of genetic data at all levels of prostate cancer management such as screening, diagnosis, treatment and follow-up in the African context. The study described here was undertaken to determine the involvement of R462Q and D541E variants of the RNASEL gene in prostate cancer in the Burkinabe population. This could provide additional information that could potentially be exploited to improve early detection and diagnosis of high-risk individuals for early therapeutic intervention or ease of management.

\section{Materials And Methods}

\section{Design of study}

The study was conducted between October 2019 and April 2021. The study population (Burkinabe) consisted of 38 patients, histologically diagnosed with prostate cancer (cases) and 53 males at least 45 years of age with either a total PSA levels less than $4 \mathrm{ng} / \mathrm{ml}$ or normals PSA derivatives (free PSA, free / total ratio, velocity and density of PSA) or a negative prostate biopsy (controls). They are all monitored at the Saint Camille hospital in Ouagadougou (HOSCO) or at the NINA clinic in Ouagadougou. Biomolecular analyzes were carried out at the Molecular and Genetic Biology Laboratory (LABIOGENE) and at the Pietro Annigoni Biomolecular Research Center (CERBA).

\section{Sample collection}

After obtaining consent from patients and controls, a questionnaire was administered to collect sociodemographic, anthropometric, and clinical data from participants. Venous blood from consenting 
participants was collected on Ethylene- Diamine-Tetra-Acetic (EDTA) filled tubes. After centrifugation, at 3,500 revolutions per minute for $15 \mathrm{~min}$, the plasma and pellet were separated and stored at $-20^{\circ} \mathrm{C}$.

\section{PSA assay}

PSA levels were assayed at the HOSCO laboratory on the Cobas 6000 automated system using the "Elecsys Total PSA" reagent. This test is an "ECLIA" electro chemiluminescence immunoassay. It is based on the "sandwich" method.

\section{DNA extraction and genotyping}

The DNA was isolated from the total blood of the participants by the technique of «salting out» as described by Miller et al. (1988). Taqman allelic discrimination was used to genotype nucleotide variants $\mathrm{R} 462 \mathrm{Q}$ (rs486907) and D541E (rs627928) of the RNASEL gene. The primers and probes for R462Q were as follows [38]: forward primer 5'-GGAAGATGTGGAAAATGAGGAAGA-3', reverse primer 5'-TGCA GATCCTGGTGGGTGTA-3', and probes 5'-VIC-CAGGACATTTCGGG CAA-MGB and 5'-FAMCAGGACATTTTGGGCAA-MGB. Primers and probes for D541E were as follows: forward primer 5'TCTATGTGGTAAAGAAGGGAAGCA-3', reverse primer 5'-TTGAAC CACCTCTTCATTACTTTGAG-3' and probes 5'-VIC-TTTCAGATCCT CAAAT-MGB and 5'-FAM-TTTCAGCTCCTCAAAT-MGB.

The target sequences were amplified by Real-time PCR in a $25 \mu \mathrm{L}$ reaction mixture consisting of $5 \mu \mathrm{L}$ of DNA, $1 \mu \mathrm{L}$ of each primer at $200 \mathrm{nmol} / \mathrm{L}$ and $0.2 \mu \mathrm{L}$ of each probe at $900 \mathrm{nmol} / \mathrm{L}, 8 \mu \mathrm{L}$ of $\operatorname{TaqMan}^{\circledR}$ Universal PCR Master Mix II 2X (Applied Biosystems), and the remainder is completed with sterile water. PCR were run on a $95^{\circ} \mathrm{C}$ program for 10 min followed by 50 cycles of denaturing at $95^{\circ} \mathrm{C}$ for $15 \mathrm{~s}$ and hybridization/extension at $60^{\circ} \mathrm{C}$ for 1 minute on QuantStudio 5 (Applied Biosystems) detection system. TaqMan Genotyper ${ }^{\circledR} 1.6 .0$ software (Applied Biosystems) was used to determine genotypes.

\section{Statement of methods}

All methods were performed in accordance with the relevant guidelines and regulations.

\section{Statistical Analyses}

Data was entered using Excel 2016 software. For each polymorphism, allelic frequencies were determined and compared between cases and controls using the $\mathrm{Chi}^{2}$ and Fisher exact tests. Hardy Weinberg's equilibrium was checked for each polymorphism. In order to verify the association between each polymorphism of the RNASEL gene and the risk of prostate cancer, the Odds ratios (OR) and 95\% confidence intervals $(95 \% \mathrm{Cl})$ were determined by considering the age at the time of the cancer diagnosis in the cases. The analyses were carried out using R 4.1.1 software. Analyses were considered statistically significant at $p \leq 0.05$.

\section{Results}




\section{Socio-demographic characteristics of the study population}

the characteristics of our study population are presented here in (Table 1).The mean age in years of the cases at the time of study was $69.81 \pm 8.05$ and $65.49 \pm 8.90$ that of the controls. The distribution by age at diagnosis shows that $60.5 \%$ of cases were diagnosed between 51 and 70 years old and $39.5 \%$ at over 70 years old. The average age at diagnosis is $67.13 \pm 8.17$ years. There is no statistically significant difference between the mean age at the diagnosis and that of the controls $(p=0.365)$. With regard to the family history of prostate cancer, $36.8 \%$ of cases and $32.1 \%$ of controls have a family history.

Table 1: Socio-demographic characteristics

$\begin{array}{llll}\text { Subgroup } & \text { Cases }(n=38) & \text { Controls }(n=53) & p \text {-value } \\ & n(\%) & n(\%)\end{array}$

Age under study(years)

\begin{tabular}{llll}
$\leq 50$ & $0(0)$ & $5(9.4)$ & \\
\hline $51-70$ & $17(44.7)$ & $35(66.0)$ & \\
\hline 70 & $21(55.3)$ & $13(24.5)$ & \\
\hline Mean (SD) & $69.81(8.05)$ & $65.49(8.90)$ & 0.017
\end{tabular}

Age at diagnostic (years)

$\leq 50 \quad 0(0)$

$51-70 \quad 23(60.5)$

\70 $15(39.5)$

Mean (SD) $\quad 67.13(8.17)$

Family history

\begin{tabular}{lll} 
Yes & $14(36.8)$ & $17(32.1)$ \\
\hline No & $18(47.4)$ & $25(47.2)$ \\
\hline unknown & $6(15.8)$ & $11(20.8)$
\end{tabular}

$S D$ : standard deviation

\section{Biological characteristics of the study population}

The distribution according to the PSA levels at diagnosis shows that the majority of cases, i.e. $81.6 \%$, have a PSA level at diagnosis greater than $20 \mathrm{ng} / \mathrm{ml}$. There is a statistically significant difference in the distribution of cases according to the PSA rate at diagnosis ( $p \otimes 0.001)$. For the Gleason score 
distribution, only $13.2 \%$ of cases have a Gleason score greater than 7 . There is a statistically significant difference in the Gleason score distribution of cases ( $p \otimes 0.001)$ (Table 2).

Table 2: Biological characteristics

\begin{tabular}{|c|c|c|c|}
\hline Subgroup & $\begin{array}{l}\text { Cases }(n=38) \\
n(\%)\end{array}$ & $\begin{array}{l}\text { Controls }(n=53) \\
n(\%)\end{array}$ & $p$-value \\
\hline \multicolumn{4}{|c|}{ PSA under study (ng/ml) } \\
\hline$\leq 4.0$ & & $37(70)$ & \\
\hline $4.1-10.0$ & & $11(21)$ & \\
\hline $10.1-20.0$ & & $3(6)$ & \\
\hline$\nabla 20$ & & $2(3)$ & \\
\hline Mean (SD) & & $4.16(4.70)$ & \\
\hline \multicolumn{4}{|c|}{ PSA at diagnosis (ng/ml) } \\
\hline$\leq 4.0$ & $0(0)$ & & \\
\hline $4.1-10.0$ & $3(7.9)$ & & \\
\hline 10.1-20.0 & $4(10.5)$ & & 0.001 \\
\hline$\otimes 20$ & $31(81.6)$ & & \\
\hline Mean (SD) & $627.85(1153.42)$ & & \\
\hline \multicolumn{4}{|c|}{ Gleason score } \\
\hline$\otimes 7$ & $10(26.3)$ & & \\
\hline 7 & $23(60.5)$ & & $\nabla 0.001$ \\
\hline$\bigotimes 7$ & $5(13.2)$ & & \\
\hline
\end{tabular}

PSA : prostate specific antigen SD : standard deviation ;

\section{Prostate cancer and lifestyle}

No association between risk of prostate cancer and lifestyle such as physical inactivity $(p=0.31)$, alcohol intake $(p=0.80)$, smoking $(p=0.62)$, and the consumption of fatty meat $(p=0.67)$ (Table 3$)$.

Table 3 : ORs for lifestyle and prostate cancer risk 
Cases (\%) Controls (\%) $\quad$ OR $\quad$ IC $95 \% \quad p$-value

Physical activity

\begin{tabular}{llllll}
\hline Yes & $22(73,3)$ & $43(82,7)$ & 1 & Reference & \\
\hline No & $8(26,7)$ & $9(17,3)$ & 1,74 & $0,59-5,13$ & 0,314 \\
\hline
\end{tabular}

Alcohol

\begin{tabular}{llllll}
\hline No & $13(43,3)$ & $24(46,2)$ & 1 & Reference & \\
\hline Yes & $17(56,7)$ & $28(53,8)$ & 1,12 & $0,45-2,77$ & 0,805 \\
\hline
\end{tabular}

Smoking

\begin{tabular}{llllll}
\hline No & $25(83,3)$ & $41(78,8)$ & 1 & Reference & \\
\hline Yes & $5(16,7)$ & $11(21,2)$ & 0,75 & $0,23-2,40$ & 0,621 \\
\hline
\end{tabular}

Fatty meat

\begin{tabular}{llllll} 
No & $12(33,3)$ & $20(37,7)$ & 1 & Reference & \\
\hline Yes & $24(66,7)$ & $33(62,3)$ & 1,21 & $0,50-2,95$ & 0,671 \\
\hline
\end{tabular}

OR : Odd Ratio ; IC : confidence interval

\section{Allelic frequencies}

For the R462Q mutation, the [G] allele was the most frequent allele in both the case population 0.868 and the control population 0.802 . There was no statistically significant difference between allele frequencies in cases and controls $(p=0.959)$. Conversely, the $[G]$ allele for the D541E variant was more prevalent among cases 0.671 and controls 0.538 . No statistically significant difference was also observed between allele frequencies in cases and controls $(p=0.881)$ (Table 4$)$. The two polymorphisms studied were in Hardy-Weinberg equilibrium in the control population ( $p=0.193$ and $p=0.203$ ). 
Table 4

Alleles frequencies

\begin{tabular}{|lllll|}
\hline SNP & Allèle & Cases $(\mathbf{n}=\mathbf{3 8})$ & Controls $(\mathbf{n = 5 3 )}$ & $\boldsymbol{p}$-value \\
\hline RNASEL R462Q & G & 0.868 & 0.802 & 0.959 \\
& A & 0.132 & 0.198 & \\
RNASEL D541E & T & 0.329 & 0.462 & 0.881 \\
\cline { 2 - 5 } & G & 0.671 & 0.538 & \\
\hline
\end{tabular}

\section{Associations of SNPs RNASEL R462Q and D541E with prostate cancer risk}

No statistically significant association between the R462Q mutation and the risk of prostate cancer was found in our study population (OR, 0.60; $95 \% \mathrm{Cl}, 0.10-3.51 ; p=0.686$ ) (Table 5).

Table 5

ORs for RNASEL 462 SNP and prostate cancer risk

\begin{tabular}{|lllll|}
\hline Genotypes & $\begin{array}{l}\text { Cases }(\mathbf{n = 3 8}) \\
\mathbf{n}(\%)\end{array}$ & $\begin{array}{l}\text { Controls }(\mathbf{n = 5} 3) \\
\mathbf{n}(\%)\end{array}$ & OR (95\% Cl) & -value \\
\hline GG & $30(78.9)$ & $36(67.9)$ & 1.0 (Reference) & \\
\hline AG & $6(15.8)$ & $13(24.5)$ & $0.55(0.19-1.63)$ & 0.281 \\
\hline AA & $2(5.3)$ & $4(7.5)$ & $0.60(0.10-3.51)$ & 0.686 \\
\hline AA vs AG/GG (Rec A) & & & $0.68(0.12,3.92)$ & 1.000 \\
\hline AAVAG vs GG (Dom A) & & $0.56(0.21,1.49)$ & 0.245 \\
\hline Rec : recessif; Dom : dominant ; OR: odds ratios; Cl: confidence interval & \\
\hline
\end{tabular}

The result found no statistically significant association between the D541E mutation and the risk of prostate cancer in our study population (OR, 2.46; 95\% Cl $0.78-7.80 ; p=0.121$ ) (Table 6). 
Table 6

ORs for RNASEL 541 SNP and prostate cancer risk

\begin{tabular}{|lllll|}
\hline Genotypes & $\begin{array}{l}\text { Cases }(\mathbf{n = 3 8}) \\
\mathbf{n}(\%)\end{array}$ & $\begin{array}{l}\text { Controls }(\mathbf{n = 5 3 )} \\
\mathbf{n}(\%)\end{array}$ & OR (95\% Cl) & p-value \\
\hline TT & $6(15.8)$ & $14(26.4)$ & 1.0 (Reference) & \\
\hline TG & $13(34.2)$ & $21(39.6)$ & $1.44(0.44-4.70)$ & 0.541 \\
\hline GG & $19(50.0)$ & $18(34.0)$ & $2.46(0.78-7.80)$ & 0.121 \\
\hline GG vs GT/TT (Rec G) & & & $1.94(0.83,4.56)$ & 0.125 \\
\hline GG/GT vs TT (Dom G) & & $1.91(0.66,5.55)$ & 0.227 \\
\hline Rec : recessif; Dom : dominant; OR: odds ratios; Cl: confidence interval & \\
\hline
\end{tabular}

\section{Combined genotypes of RNASEL R462Q and D541E linked to prostate cancer}

This study found no statistically significant association between the risk of prostate cancer and the different combinations of genotypes of the mutations of the R462Q and D541E polymorphisms (Table 7).

Table 7

ORs for RNASEL 462/541 combined genotypes and prostate cancer risk

\begin{tabular}{|lllll|}
\hline Combined genotypes 462/541 & Cases $(n=38)$ & Controls $(n=51)$ & OR $(\mathbf{9 5 \%}$ Cl) & $p$-value \\
\hline GG/TT & 6 & 13 & 1.0 (Reference $)$ & \\
\hline GG/GT & 12 & 14 & $1.85(0.54-6.40)$ & 0.497 \\
\hline GG/GG & 12 & 9 & $2.89(0.79-10.57)$ & 0.192 \\
\hline AG/GG & 5 & 7 & $1.52(0.34-6.94)$ & 0.852 \\
\hline AG/GT & 1 & 6 & $0.36(0.00-4.33)$ & 0.628 \\
\hline AA/GG & 2 & 2 & $2.16(0.12-35.61)$ & 0.589 \\
\hline
\end{tabular}

\section{Associations of SNPs RNASEL R462Q and D541E with Gleason score}

The R462Q and D541E mutations were compared between patients according to the Gleason score ( $\leq 7$ and $\otimes 7)$. 
For the R462Q mutation, 33.3\% of carriers of the AG genotype and 10.0\% of carriers of the GG genotype have a Gleason score greater than seven (7) while $100 \%$ of carriers of AA genotypes have a score of seven at more (Figure 1). We found a statistically significant association between the R462Q mutation and the Gleason score $(p \otimes 0.001)$.

For the D541E mutation, $21.1 \%$ of carriers of the GG genotype and $7.7 \%$ of carriers of the GT genotype had a Gleason score greater than 7 while $100 \%$ of carriers of TT genotypes had a score of 7 at more (Figure 2). We found a statistically significant association between the D541E mutation and the Gleason score $(p \otimes 0.001)$.

\section{Associations of SNPs RNASEL R462Q and D541E with PSA at diagnosis}

The PSA levels at diagnosis according to the different genotypes of the R462Q mutation indicate that $100 \%$ of carriers of the AA genotypes have PSA greater than $20 \mathrm{ng} / \mathrm{ml}$. Only carriers of the GG genotype (13.3\%) present PSA levels between 10.1 and $20 \mathrm{ng} / \mathrm{ml}$ (Figure 3). No association was found between this mutation and the PSA level at diagnosis greater than $20 \mathrm{ng} / \mathrm{ml}(p=0.773)$.

For the D541E mutation, $89.4 \%$ of the GG genotype have a PSA level greater than $20 \mathrm{ng} / \mathrm{ml} .23 .1 \%$ of carriers of the heterozygous GT genotype and $5.3 \%$ of carriers of the mutated GG genotype had a PSA level at diagnosis between 10.1 and $20 \mathrm{ng} / \mathrm{ml}$ (Figure 4). No association was found between this mutation and PSA levels at diagnosis greater than $20 \mathrm{ng} / \mathrm{ml}(p=0.346)$.

\section{Discussion}

Sociodemographic characteristics show that the mean age at diagnosis of cases was high, at $67.13 \pm$ 8.17 years. This result is not different from that of Kaboré et al. [39] who report an average age of 71.5 years in Burkina Faso. These results indicate that the age at diagnosis in Burkina Faso is high as observed elsewhere in West Africa [40]. But our results are contrary to those obtained in various studies reporting when black men have an age at early diagnosis [41-43]. PSA levels at diagnosis were very high in our study with a mean of $627.85 \pm 1153.42 \mathrm{ng} / \mathrm{ml}$. Our results are in agreement with those obtained by Kaboré et al. in Burkina Faso with an average PSA of $537 \mathrm{ng} / \mathrm{ml}$ [35]. Our results corroborate those of Niang et al. in Senegal and Ofoha and Magnus in Nigeria [37, 44]. Tengue et al. in Togo also found PSA levels at diagnosis greater than $100 \mathrm{ng} / \mathrm{ml}$ [36]. Among the cases with their Gleason score, $82.14 \%$ have a score less than or equal to 7 . This shows that the majority of these cases presented a moderately differentiated tumor at diagnosis. These different results show, on the one hand, that the diagnosis of prostate cancer is made at advanced stages of the disease and, on the other hand, the absence of prostate cancer screening programs. Regarding the family history of prostate cancer, of the 32 cases with a family history, $43.8 \%$ have a family history while $56.2 \%$ did not. These results could show that the majority of prostate cancer cases in our study population are not familial. But this trend could be due to the fact that the information was collected on the basis of verbal testimonies and not on the basis of 
medical records. Indeed, patients could confuse other prostate conditions (benign hypertrophy...) and prostate cancer.

Regarding alcohol consumption, our results are similar to those obtained by Dennis et al. [45] who found only a strong association between alcohol consumption and prostate cancer mortality. Our results do not support those obtained by Middleton et al. in 2009 [46] and Rota et al. in 2012 [47] in their meta-analyzes. As for cigarette consumption, our results are different from those obtained by Jones et al. in England; Cerhan et al. in the United States and Giovannucci et al. also in the United States [48-50]. All these different studies have only shown a slight increase in the risk of developing prostate cancer while a strong association was found with mortality. No association was found between physical activity and prostate cancer in our study. Our results do not corroborate those of Guéritat in France. This study demonstrated that physical exercise prevents the progression of prostate cancer either by regulating redox status and redox-dependent signaling pathways, or via the modulation of cholesterolemia or even of the expression profile of miRNAs [51]. Considering the consumption of fatty meat, our results corroborate those of Park et al. in their study of a population of Hawaii and Los Angeles and those of Dennis et al. in their meta-analysis of 4 cohort studies [45, 52].

Linkage analyzes of families at high risk for prostate cancer have provided convincing evidence that the HPC1 locus is likely to harbor a prostate cancer susceptibility gene [53]. The RNASEL gene has been proposed as a putative tumor suppressor gene located in this region by the positional cloning technique and by the candidate gene approach [54]. Association analyzes of the R462Q and D541E variants within the RNASEL gene with the Prostate cancer have achieved controversial results. Analysis of the different genotypes of the R462Q variant in our study population showed no association of this variant with prostate cancer. Our results support the conclusions of Wei et al.; Noonan et al.; and Alvarez et al. [21, 29, 30] as well as those of Fredrik et al. [34]. These studies found no association between the R462Q variant and prostate cancer. However, Casey et al. and Xiang et al. [30, 31] show that the AA genotype of the $\mathrm{R} 462 \mathrm{Q}$ variant is significantly associated with prostate cancer. Regarding the D541E variant, our study found no association with prostate cancer. This goes hand in hand with the studies of Wei et al.; Ignacio et al:; Shook et al. [38, 55, 56] as well as several other authors [29, 30, 57, 58]. Contrary to our results, Noonan-Wheeler et al. and Wiklund et al. [33,34] in a Swedish population observed an association between the GG genotype and an increased risk of prostate cancer.

Our results showed an association between the R462Q mutation and the degree of tumor differentiation $(p \otimes 0.001)$. Indeed, carriers of heterozygous AG genotype (33.3\%) and normal GG genotype $(10.0 \%)$ presented undifferentiated tumors (Gleason $\otimes 7$ ) unlike carriers of mutated genotype. Our results are identical to those obtained by Alvarez-Cubero et al. in Spain [59]. On the other hand, San Francisco et al. found no association between the R462Q mutation and Gleason score [56]. For the D541E mutation, we also found an association with the degree of tumor differentiation. By observing closely, it can be seen that $21.1 \%$ of the undifferentiated tumors were carriers of the mutated GG genotype against $7.7 \%$ and $0 \%$ for carriers of the heterozygous and homozygous TT genotype respectively ( $p \otimes 0.001)$. The same result was obtained by San Francisco et al. in Chile [56]. In contrast, Alvarez et al. found no association between 
this mutation and the Gleason score [59]. We found no association between R462Q and D541E mutations with PSA levels at diagnosis. This shows that these two mutations in the RNASEL gene are not associated with the level of risk of the tumor (PSA level at diagnosis). Indeed, the PSA level at diagnosis makes it possible to measure the level of risk of tumor progression. For PSA values at diagnosis greater than $20 \mathrm{ng} / \mathrm{ml}$, the tumor is considered to be at high risk [60].

The differences between our results and other studies may, on the one hand, be justified by the difference in sample sizes; the method of selection of controls and, on the other hand, by the ethno-geographic differences of the study populations. Indeed, the small size of the samples lacks the statistical power to detect associations. Also, the genetic predisposition to prostate cancer is heterogeneous (contribution of environmental and genetic factors) in its hereditary form [61] and involves the predisposition genes in a variable way depending on ethno-geographic origins.

\section{Conclusion}

Our study is a first to explore the links that could exist between the Arg46Gln and D541E variants of the RNASEL gene and prostate cancer in Burkina Faso. Genetically, the [G] allele of the R462Q variant and the [G] allele of the D541E variant were the most common in our study population. There is no difference in allele frequencies between cases and controls. These variants, taken alone or in combination, are not associated with the risk of prostate cancer in Burkina Faso population.

\section{Abbreviations}

D541E: aspartic acid 541glutamic acid; ECLIA: Electro chemiluminescence immunoassay; HPC1: Hereditary Prostate Cancer 1; MSR1: Macrophage Scavenger Receptor1 Pca: Prostate cancer; PSA: Prostate specific antigen; R462Q: arginine 462 glutamine; RNASEL: 2'-5' oligoadenylate synthetasedependent ribonuclease.

\section{Declarations}

\section{Ethics approval and consent to participate}

Our study obtained the approval of the Ethics Committee of CERBA / LABIOGENE. All participants gave their free and informed consent. The study scrupulously respected confidentiality and anonymity.

\section{Consent for publication}

Not applicable

\section{Availability of data and materials}

Not applicable 


\section{Competing interests}

The authors state no conflict of interest.

\section{Funding}

This study was funded by CERBA/LABIOGENE.

\section{Authors' contributions}

E.K. and J.S. designed this study. E.K., T.M.Z., B.D.K. and A.T. recruited patients and controls. E.K., A.A.Z., L.T., A.T.Y., B.V.J.T.E.B., H.K.S., P.A.S., T.F., K.T. and C.O. carried out the manipulations. E.K., A.A.Z. carried out statistical analyses and wrote the manuscript. F.W.D. and J.S. revised the manuscript. All authors have read and corrected the manuscript

\section{Acknowledgements}

We thank the Saint Camille hospital in Ouagadougou (HOSCO) and NINA clinic in Ouagadougou for hosting the study, the participants for agreeing to be part of the study, and CERBA/LABIOGENE for the technical platform for molecular testing.

\section{References}

1. Sung H, Ferlay J, Siegel RL, Laversanne M, Soerjomataram I, Jemal A, et al. Global cancer statistics 2020: GLOBOCAN estimates of incidence and mortality worldwide for 36 cancers in 185 countries. CA Cancer J Clin. 4 feb 2021;

2. Pienta KJ, Esper PS. Risk factors for prostate cancer. Ann Intern Med. 15 may 1993;118(10):793803.

3. Bostwick DG, Burke HB, Djakiew D, Euling S, Ho S, Landolph J, et al. Human prostate cancer risk factors. Cancer. 2004;101(S10):2371-490.

4. Dagnelie PC, Schuurman AG, Goldbohm RA, Van den Brandt PA. Diet, anthropometric measures and prostate cancer risk: a review of prospective cohort and intervention studies. BJU Int. mai 2004;93(8):1139-50.

5. Perdana NR, Mochtar CA, Umbas R, Hamid ARA. The Risk Factors of Prostate Cancer and Its Prevention: A Literature Review. Acta Med Indones. jul 2016;48(3):228-38.

6. Scardino PT. Early detection of prostate cancer. Urol Clin North Am. nov 1989;16(4):635-55.

7. Kheirandish $\mathrm{P}, \mathrm{Chinegwundoh} \mathrm{F}$. Ethnic differences in prostate cancer. $\mathrm{Br} \mathrm{J}$ Cancer. 9 aug 2011;105(4):481-5.

8. Whittemore AS, Wu AH, Kolonel LN, John EM, Gallagher RP, Howe GR, et al. Family history and prostate cancer risk in black, white, and Asian men in the United States and Canada. Am J Epidemiol. 15 apr 1995;141(8):732-40. 
9. Albright FS, Stephenson RA, Agarwal N, Cannon-Albright LA. Relative Risks for Lethal Prostate Cancer Based on Complete Family History of Prostate Cancer Death. Prostate. 2017;77(1):41-8.

10. Gallagher RP, Fleshner N. Prostate cancer: 3. Individual risk factors. CMAJ. 6 oct 1998;159(7):80713.

11. Hernández J, Thompson IM. Prostate-specific antigen: a review of the validation of the most commonly used cancer biomarker. Cancer. 1 sept 2004;101(5):894-904.

12. Hernández J, Balic I, Johnson-Pais TL, Higgins BA, Torkko KC, Thompson IM, et al. Association between an estrogen receptor alpha gene polymorphism and the risk of prostate cancer in black men. J Urol. feb 2006;175(2):523-7.

13. Ahlbom A, Lichtenstein P, Malmström H, Feychting M, Hemminki K, Pedersen NL. Cancer in twins: genetic and nongenetic familial risk factors. J Natl Cancer Inst. 19 feb 1997;89(4):287-93.

14. Page WF, Braun MM, Partin AW, Caporaso N, Walsh P. Heredity and prostate cancer: a study of World War Il veteran twins. Prostate. 1 dec 1997;33(4):240-5.

15. Mucci LA, Hjelmborg JB, Harris JR, Czene K, Havelick DJ, Scheike T, et al. Familial Risk and Heritability of Cancer Among Twins in Nordic Countries. JAMA. 5 jan 2016;315(1):68-76.

16. Cussenot $\mathrm{O}$, Cancel-Tassin $\mathrm{G}$. Facteurs de risque génétiques pour le cancer de la prostate. ms. 2004;20(5):562-8.

17. Xu J. Combined analysis of hereditary prostate cancer linkage to 1q24-25: results from 772 hereditary prostate cancer families from the International Consortium for Prostate Cancer Genetics. Am J Hum Genet. march 2000;66(3):945-57.

18. Simard J, Dumont M, Labuda D, Sinnett D, Meloche C, El-Alfy M, et al. Prostate cancer susceptibility genes: lessons learned and challenges posed. Endocr Relat Cancer. jun 2003;10(2):225-59.

19. Agalliu I, Leanza SM, Smith L, Trent JM, Carpten JD, Bailey-Wilson JE, et al. Contribution of HPC1 (RNASEL) and HPCX variants to prostate cancer in a founder population. The Prostate. 2010;70(15):1716-27.

20. Fesinmeyer MD, Kwon EM, Fu R, Ostrander EA, Stanford JL. Genetic variation in RNASEL and risk for prostate cancer in a population-based case-control study. Prostate. 1 oct 2011;71(14):1538-47.

21. Zuo L, Ren K-W, Bai Y, Zhang L-F, Zou J-G, Qin X-H, et al. Association of a common genetic variant in RNASEL and prostate cancer susceptibility. Oncotarget. 5 sept 2017;8(43):75141-50.

22. Rebbeck TR, Walker AH, Zeigler-Johnson C, Weisburg S, Martin AM, Nathanson KL, et al. Association of HPC2/ELAC2 genotypes and prostate cancer. Am J Hum Genet. oct 2000;67(4):1014-9.

23. Alvarez-Cubero MJ, Saiz M, Martinez-Gonzalez LJ, Alvarez JC, Lorente JA, Cozar JM. Genetic analysis of the principal genes related to prostate cancer: a review. Urol Oncol. nov 2013;31(8):141929.

24. Tan S-H, Petrovics G, Srivastava S. Prostate Cancer Genomics: Recent Advances and the Prevailing Underrepresentation from Racial and Ethnic Minorities. Int J Mol Sci [Internet]. 22 avr 2018 [cité 10 dec 2020];19(4). Disponible sur: https://www.ncbi.nlm.nih.gov/pmc/articles/PMC5979433/ 
25. Ewing CM, Ray AM, Lange EM, Zuhlke KA, Robbins CM, Tembe WD, et al. Germline mutations in HOXB13 and prostate-cancer risk. N Engl J Med. 12 jan 2012;366(2):141-9.

26. Pilie PG, Giri VN, Cooney KA. HOXB13 and other high penetrant genes for prostate cancer. Asian Journal of Andrology. 7 jan 2016;18(4):530.

27. Pritchard CC, Mateo J, Walsh MF, De Sarkar N, Abida W, Beltran H, et al. Inherited DNA-Repair Gene Mutations in Men with Metastatic Prostate Cancer. N Engl J Med. 4 aug 2016;375(5):443-53.

28. Zhou A, Hassel BA, Silverman RH. Expression cloning of 2-5A-dependent RNAase: a uniquely regulated mediator of interferon action. Cell. 12 march 1993;72(5):753-65.

29. Rökman A, Ikonen T, Seppälä EH, Nupponen N, Autio V, Mononen N, et al. Germline alterations of the RNASEL gene, a candidate HPC1 gene at 1q25, in patients and families with prostate cancer. Am J Hum Genet. may 2002;70(5):1299-304.

30. Casey G, Neville PJ, Plummer SJ, Xiang Y, Krumroy LM, Klein EA, et al. RNASEL Arg462GIn variant is implicated in up to $13 \%$ of prostate cancer cases. Nat Genet. dec 2002;32(4):581-3.

31. Xiang Y, Wang Z, Murakami J, Plummer S, Klein EA, Carpten JD, et al. Effects of RNase L mutations associated with prostate cancer on apoptosis induced by 2',5'-oligoadenylates. Cancer Res. 15 oct 2003;63(20):6795-801.

32. Nakazato H, Suzuki K, Matsui H, Ohtake N, Nakata S, Yamanaka H. Role of genetic polymorphisms of the RNASEL gene on familial prostate cancer risk in a Japanese population. Br J Cancer. 18 august 2003;89(4):691-6.

33. Noonan-Wheeler FC, Wu W, Roehl KA, Klim A, Haugen J, Suarez BK, et al. Association of hereditary prostate cancer gene polymorphic variants with sporadic aggressive prostate carcinoma. Prostate. 1 jan 2006;66(1):49-56.

34. Wiklund F, Jonsson B-A, Brookes AJ, Strömqvist L, Adolfsson J, Emanuelsson M, et al. Genetic analysis of the RNASEL gene in hereditary, familial, and sporadic prostate cancer. Clin Cancer Res. 1 nov 2004;10(21):7150-6.

35. Kabore FA, Kambou T, Zango B, Ouédraogo A. Knowledge and awareness of prostate cancer among the general public in Burkina Faso. J Cancer Educ. march 2014;29(1):69-73.

36. Tengue K, Kpatcha TM, Botcho G, Leloua E, Amavi AK, Sikpa K, et al. Profil épidémiologique, diagnostique, thérapeutique et évolutif du cancer de la prostate au Togo. African Journal of Urology. 1 jun 2016;22(2):76-82.

37. Niang L, Ndoye M, Ouattara A, Jalloh M, Labou M, Thiam I, et al. [Management of prostate cancer in Senegal: what is being done?]. Prog Urol. jan 2013;23(1):36-41.

38. Shook SJ, Beuten J, Torkko KC, Johnson-Pais TL, Troyer DA, Thompson IM, et al. Association of RNASEL Variants with Prostate Cancer Risk in Hispanic Caucasians and African Americans. Clin Cancer Res. 1 oct 2007;13(19):5959-64.

39. Kabore F, Zango B, Kambou T, Yameogo C, Kirakoya B. Cancer de la prostate au Burkina Faso: caractéristiques diagnostics et indications thérapeutiques initiales. Progrès en Urologie. 1 nov 2013;23:1075. 
40. Ajape AA, Ibrahim KOO, Fakeye JA, Abiola OO. An overview of cancer of the prostate diagnosis and management in Nigeria: the experience in a Nigerian tertiary hospital. Ann Afr Med. sept 2010;9(3):113-7.

41. Freedland SJ, Sutter ME, Naitoh J, Dorey F, Csathy GS, Aronson WJ. Clinical characteristics in black and white men with prostate cancer in an equal access medical center. Urology. march 2000;55(3):387-90.

42. Barros MS, Silva VRS, Santos GB, Hughes A, Silveira MA. Prevalence of prostate adenocarcinoma according to race in an university hospital. International braz j urol. august 2003;29(4):306-12.

43. Odedina FT, Ogunbiyi JO, Ukoli FAM. Roots of prostate cancer in African-American men. J Natl Med Assoc. apr 2006;98(4):539-43.

44. Ofoha CG, Magnus FE. Presentation, Characteristics and Co-morbidities of Men with Prostate Cancer in Nigeria. JAMMR. 2 dec 2019;1-7.

45. Dennis LK. Meta-analysis for combining relative risks of alcohol consumption and prostate cancer. Prostate. jan 2000;42(1):56-66.

46. Middleton Fillmore K, Chikritzhs T, Stockwell T, Bostrom A, Pascal R. Alcohol use and prostate cancer: a meta-analysis. Mol Nutr Food Res. feb 2009;53(2):240-55.

47. Rota M, Scotti L, Turati F, Tramacere I, Islami F, Bellocco R, et al. Alcohol consumption and prostate cancer risk: a meta-analysis of the dose-risk relation. Eur J Cancer Prev. jul 2012;21(4):350-9.

48. Jones MR, Joshu CE, Kanarek N, Navas-Acien A, Richardson KA, Platz EA. Cigarette Smoking and Prostate Cancer Mortality in Four US States, 1999-2010. Prev Chronic Dis [Internet]. 14 apr 2016 [cité 6 mai 2021];13. Disponible sur: https://www.ncbi.nlm.nih.gov/pmc/articles/PMC4852753/

49. Cerhan JR, Torner JC, Lynch CF, Rubenstein LM, Lemke JH, Cohen MB, et al. Association of smoking, body mass, and physical activity with risk of prostate cancer in the lowa 65+ Rural Health Study (United States). Cancer Causes Control. march 1997;8(2):229-38.

50. Giovannucci E, Rimm EB, Ascherio A, Colditz GA, Spiegelman D, Stampfer MJ, et al. Smoking and Risk of Total and Fatal Prostate Cancer in United States Health Professionals. Cancer Epidemiol Biomarkers Prev. 1 apr 1999;8(4):277-82.

51. Guéritat J. Exercice physique et progression du cancer de la prostate: effets combinés avec la prise d'antioxydants naturels ou la radiothérapie externe : identification de voies de signalisation redoxdépendantes [Internet] [phdthesis]. Université Rennes 2; 2015 [cité 15 apr 2021]. Disponible sur: https://tel.archives-ouvertes.fr/tel-01143870

52. Park S-Y, Murphy SP, Wilkens LR, Henderson BE, Kolonel LN. Fat and meat intake and prostate cancer risk: The multiethnic cohort study. International Journal of Cancer. 2007;121(6):1339-45.

53. Smith JR, Freije D, Carpten JD, Grönberg H, Xu J, Isaacs SD, et al. Major susceptibility locus for prostate cancer on chromosome 1 suggested by a genome-wide search. Science. 22 nov 1996;274(5291):1371-4.

54. Carpten J, Nupponen N, Isaacs S, Sood R, Robbins C, Xu J, et al. Germline mutations in the ribonuclease L gene in families showing linkage with HPC1. Nat Genet. feb 2002;30(2):181-4. 
55. Wei B, Xu Z, Ruan J, Zhu M, Jin K, Zhou D, et al. RNASEL Asp541Glu and Arg462Gln polymorphisms in prostate cancer risk: evidences from a meta-analysis. Mol Biol Rep. march 2012;39(3):2347-53.

56. San Francisco IF, Rojas PA, Torres-Estay V, Smalley S, Cerda-Infante J, Montecinos VP, et al. Association of RNASEL and 8q24 variants with the presence and aggressiveness of hereditary and sporadic prostate cancer in a Hispanic population. J Cell Mol Med. jan 2014;18(1):125-33.

57. Wang L, McDonnell SK, Elkins DA, Slager SL, Christensen E, Marks AF, et al. Analysis of the RNASEL gene in familial and sporadic prostate cancer. Am J Hum Genet. jul 2002;71(1):116-23.

58. Maier C, Haeusler J, Herkommer K, Vesovic Z, Hoegel J, Vogel W, et al. Mutation screening and association study of RNASEL as a prostate cancer susceptibility gene. $\mathrm{Br} \mathrm{J}$ Cancer. 28 march 2005;92(6):1159-64.

59. Alvarez-Cubero MJ, Pascual-Geler M, Martinez-Gonzalez LJ, Expósito Ruiz M, Saiz M, Cozar JM, et al. Association between RNASEL, MSR1, and ELAC2 single nucleotide polymorphisms and gene expression in prostate cancer risk. Urol Oncol. oct 2016;34(10):431.e1-8.

60. Hull GW, Rabbani F, Abbas F, Wheeler TM, Kattan MW, Scardino PT. Cancer control with radical prostatectomy alone in 1,000 consecutive patients. J Urol. feb 2002;167(2 Pt 1):528-34.

61. Karayi MK, Neal DE, Markham AF. Current status of linkage studies in hereditary prostate cancer: LINKAGE STUDIES IN HEREDITARY PROSTATE CANCER. BJU International. 24 dec 2001;86(6):65969.

\section{Figures}

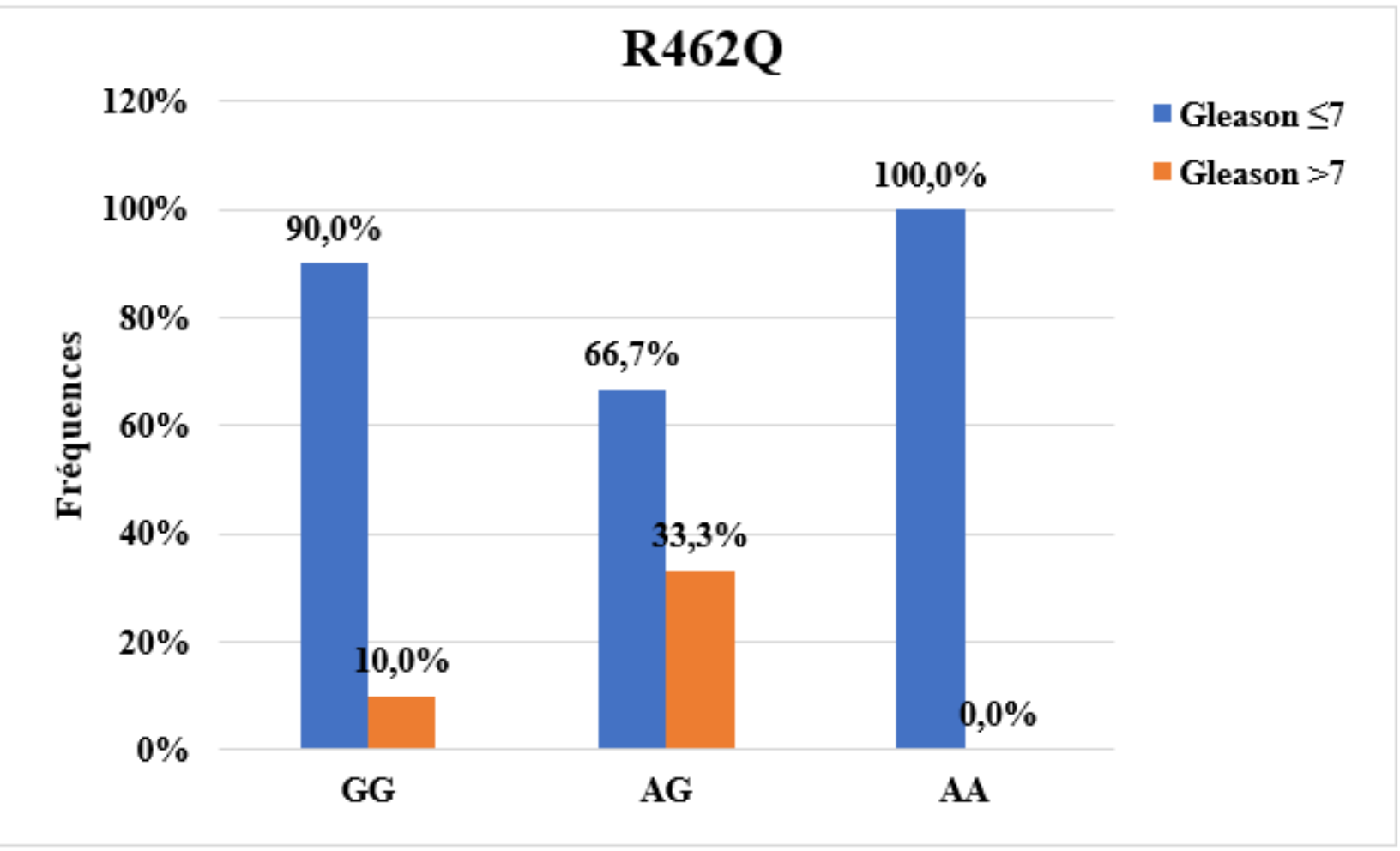

Figure 1 


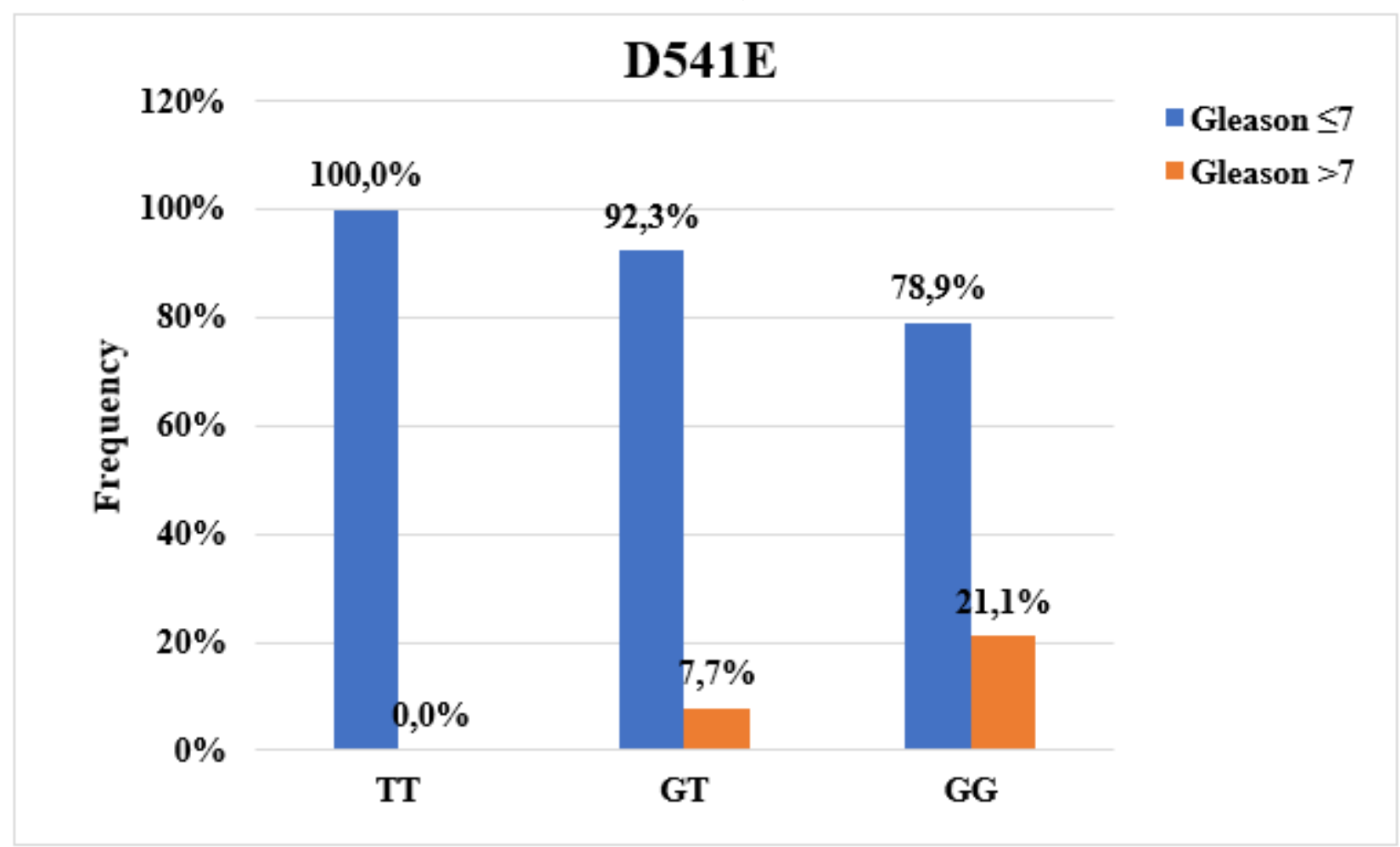

Figure 2

Association between Gleason score and D541E mutation

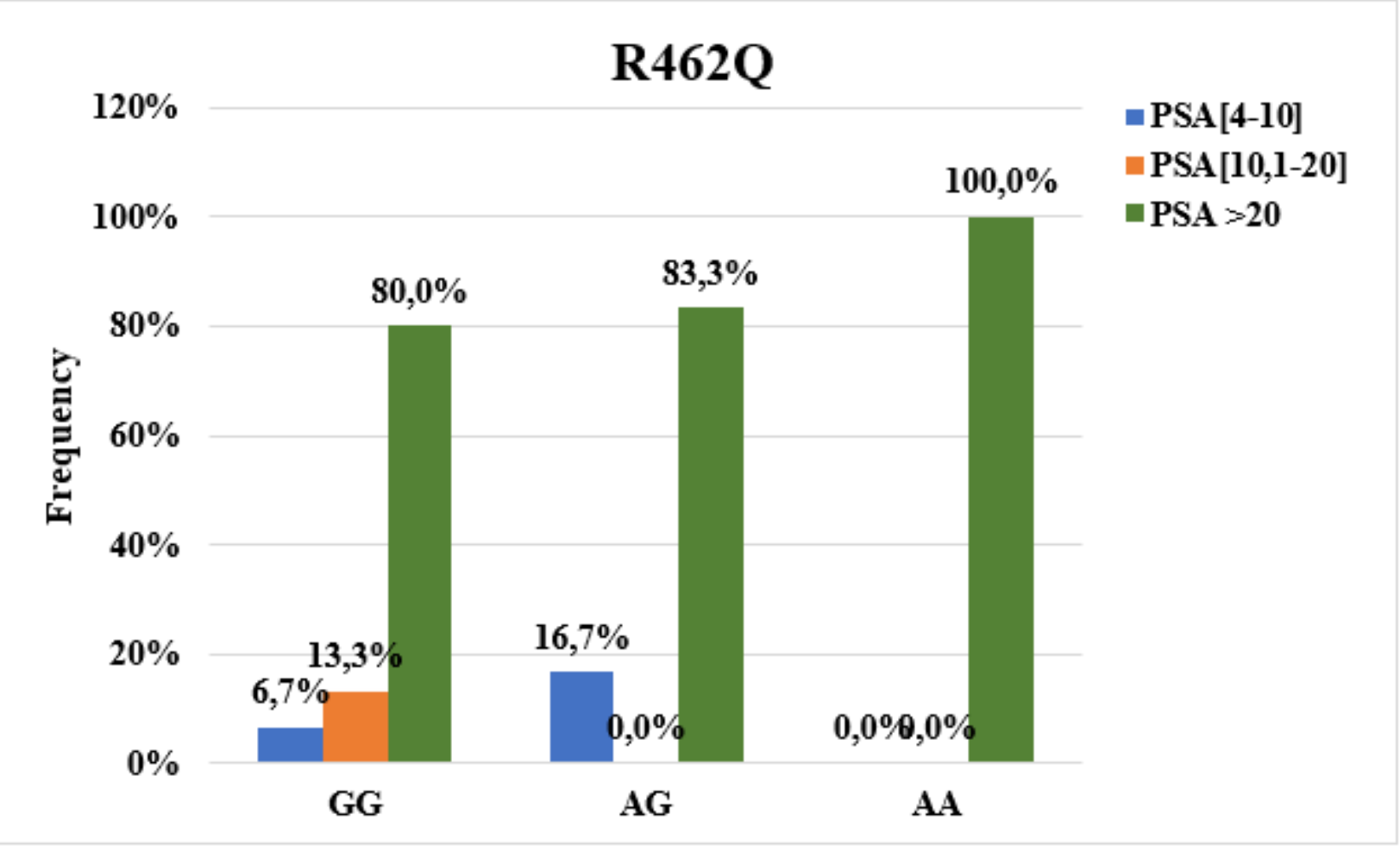

Figure 3

Association between PSA level at diagnostic and R462Q mutation 


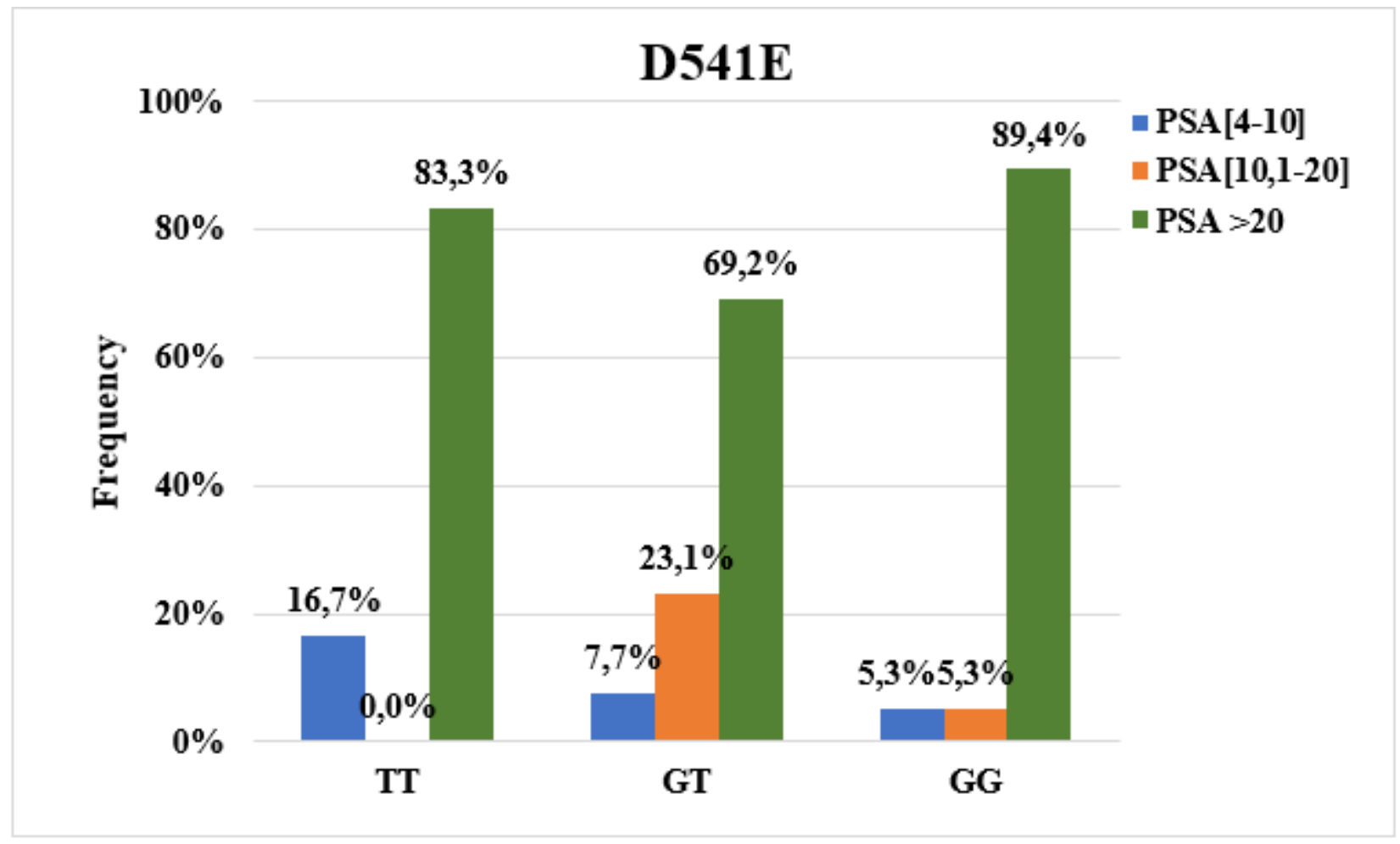

Figure 4

Association between PSA level at diagnostic and D541E mutation 